\title{
O RYZYKU [KRY]ĄCYM SIĘ ZA MITOLOGIZACJĄ/POLITYZACJĄ HISTORII) SŁÓW KILKA
}

\author{
Marek WOŹNIAK
}

\section{ABSTRACT}

\section{A FEW WORDS ABOUT THE HIDDEN RISK}

(OF THE MYTHOLOGIZATION/POLITICIZATION OF HISTORY)

Arguments about history (as like as politics) is certainly not newfangled or unexpected. The competing visions of the past (winners and losers) are not, however, just a dispute over what and how it happened. On the contrary, it is not difficult to see that they influence not only upon the domination of the "piloted" vision of the past, but also on a particular social/ political order. Therefore in this article I try to show some risk behind the mythologization and politicization of the historical discourse.

\section{KEYWORDS:}


Spory o historię (podobnie jak o politykę) są w moim przekonaniu czymś naturalnym, a jeśli nawet nie, to z pewnością nie są czymś nowym czy nieoczekiwanym. W zasadzie od początku refleksji - czy jedynie myślenia/wspominania/upamiętniania - człowieka nad własną przeszłością, jednym z pewników było, że znajdzie się ktoś, kto będzie pamiętał/opowiadał inaczej, a wizerunek przeszłości, a także to, co z niej zapamiętamy/ zechcemy zapamiętać, zależy od tego, kto o niej opowiada. Popularna maksyma: „historię piszą zwycięzcy” kryje w sobie przesłanie, równie ważne, jeśli nie ważniejsze niż to, co mówi nam wprost - historia pokonanych jest/ może być inna. Konkurujące między sobą narracje (zwycięzców i zwyciężonych), w taki czy inny sposób przedstawiające przeszłość, nie są jednak dziś - tak jak nie byly często w przeszłości - jedynie sporem o to, co i jak było/ miało miejsce. Przeciwnie, zgadzając się z postawioną przez Jana Pomorskiego tezą, mówiącą o istnieniu swego rodzaju sprzężenia zwrotnego pomiędzy historiografią a aktualnym układem stosunków społeczno-politycznych', nietrudno dostrzec, że (potencjalnie) wpływają lub chcą wpływać nie tylko na uobecnienie i dominację „pilotowanej” przez siebie wizji przeszłości, ale próbują także - często skutecznie - konstytuować określony porządek/ ład prawny i społeczno-ustrojowy (patrz na przykład: ustawa o ochronie „dobrego imienia Polski i Polaków")2.

Legitymizacja miejsca na scenie społeczno-politycznej i waloryzacja podejmowanych dziś działań - przez odwołanie się do takiej a nie innej wizji przeszłości - prowadzi nie tylko do swoistej mitologizacji historii, pojmowanej, jak chce Jan Pomorski, jako intencjonalne tworzenie i postugiwanie się mitami dla potrzeb socjalizacji danej wspólnoty, ale przede wszystkim do jej polityzacji, rozumianej jako intencjonalne podporządkowanie narracji historycznej bieżacym racjom politycznym danej wspólnoty ${ }^{3}$. I choć, jak sądzi Pomorski, działania takie są nie tylko szeroko rozpowszechnionymi pozanaukowymi praktykami społecznymi, spotykanymi we wszystkich krajach (a więc nie jest to jakaś <<specyfika>> Polski), to trudno przejść wobec nich obojętnie i godzić się na konsekwencje owych działań. Nawet jeśli, choć trudno mi się z tym identyfi-

Zob.: http://pth.net.pl/uploads/forum_badaczy_dn/Polityzacja_historii.pdf, s. 3. A nieco dalej dodaje: Istniejący układ tych stosunków, poszukując akceptacji dla siebie w świadomości społecznej, „domaga się” od historiografi swoistej legitymacji historycznej, zakorzenienia swych praw dzisiejszych w tradycji narodowej. A ponieważ w ramach społeczeństwa istnieje zawsze jakaś polaryzacja sit spotecznych i opcji politycznych, możemy zaobserwować, jak poszczególne grupy społeczne, klasy i partie polityczne „pilotują" swoje wizje przeszłości, określony typ narracji historycznej, starając się, aby upowszechnit się on, zapanowat wświadomości spotecznej, wypierając z niej wizje pozostałe.

2 Patrz więcej: https://ms.gov.pl/pl/informacje/news,8528,ochrona-dobrego-imienia-polski--projektprzyjety.html [dostęp: 15-06-2017], http://www.rp.pl/Prawo-karne/302159929-Dobre-imie-Polski-i-Polakowma-byc-chronione-prawem.html [dostęp: 15-06-2017].

3 Tamże, s. 2. 
kować, dla zachowania tej części jej tożsamości, która oparta jest na wspólnie przeżytej i podzielanej historii, mitologizacja/polityzacja historii jest warunkiem niezbędnym, acz niewystarczajacym, przetrwania każdej wspólnoty ${ }^{4}$, nie znaczy to jednak, że powinniśmy się na to godzić, a przynajmniej nie w tej formule, która jest realizowana dziś w Polsce. Socjalizacja przeszłościa - wokół przeszłości/ przez przeszłość - może być elementem służącym lub mogącym służyć budowaniu tego, co nazywane jest dziś kapitatem społecznym $m^{5}$, ale z pewnością nie wtedy, kiedy ma miejsce wokół jednej (właściwej) jej interpretacji. W takiej sytuacji prowadzi bowiem do uniformizacji myślenia, jest anty- i a-refleksyjna, nie tyle „socjalizuje”, co zwalnia z myślenia, narzuca i zamyka.

Problem pojawia się zatem nie tyle/ nie tylko w momencie, gdy (określona) wizja przeszłości staje się fundamentem podejmowanych działań (ich legitymizacji i waloryzacji) - czy może raczej staje za podejmowanymi decyzjami - ale wtedy, gdy za zwracanie uwagi na odcienie szarości - na przykład w promowanej czarno-białej wizji historii („żołnierzy wyklętych”) - historykowi (homo metahistoricus) przykleja się latkę „lewackiego publicysty” („Gazety Wyborczej”); kiedy taka czy inna interpretacja przeszłości/biografii staje się przesłanką zwolnienia z pracy; kiedy taki czy inny obraz II wojny światowej wplywa na decyzje polityczne i administracyjne, a zatem wtedy, kiedy (określona) interpretacja przeszłości kryje się za stanowiskiem politycznym lub wręcz staje się (i jest tak postrzegana) stanowiskiem politycznym, a ostatecznie rozstrzyga także o przypisywaniu przeciwnikom (politycznym w gruncie rzeczy), takich czy innych kwalifikacji moralnych i etycznych. I choć rację ma Pomorski, kiedy pisze, że poprawność polityczna jest zawsze wyrazem przemocy intelektualnej, stosowanej wobec uczestników publicznej debaty, to nie można pominąć milczeniem sytuacji, w której krytycy „poprawności politycznej”, nie dostrzegają nic niestosownego w karaniu „(nie)poprawności historycznej”, nie widzą nic złego w narzucaniu określonego światopoglądu/światooglądu, próbują wreszcie decydować o dopuszczalnym języku dyskursu, wyznaczaniu granic i ram możliwych/akceptowalnych „gier kulturowych”.

\footnotetext{
4 Tamże.

5 Jak pisze Pomorski: Chodzi tu o specjalny, niematerialny rodzaj aktywów, jakie dana wspólnota posiadao więzi i zaufanie, wytworzone w przestrzeni międzyludzkich relacji na bazie wspólnie podzielanych wartości, przekonań i idei, dz. cyt., s. 2 .

6 Przykładem może tu być nie tylko wspomniana wyżej ustawa o karaniu przestępstw/zbrodni przeciwko narodowi polskiemu, ale także sprawa jednego z historyków lubelskiego oddziału IPN, związana z kontrowersją wokół patronatu jednej z ulic Lublina, patrz: http://www.kurierlubelski.pl/wiadomosci/lublin/a/czy-szef-ipn-w-lubliniezwolni-historyka-macieja-sobieraja,11911720/ [dostęp: 15-06-2017]; http://www.dziennikwschodni.pl/lublin/ cichociemny-patronem-ulicy-w-lublinie-historyk-ipn-skrytykowal-pomysl-teraz-moze-stracic-prace,n,1000196332. html [dostęp: 15-06-2017]; http://www.dziennikwschodni.pl/lublin/dyrektor-ipn-wypowiedzial-sie-ws-historyka-ktorymial-inne-zdanie,n,1000196674.html [dostęp: 15-06-2017].
} 
Godząc się zatem na mitologizację/polityzację historii - także jako niezwykle wygodnego, a przy okazji efektywnego narzędzia socjalizacji wokół pewnych wartości i budowy „kapitału społecznego” - warto się zastanowić czy nie godzimy się jednocześnie na ostracyzm „myślących inaczej”, a zatem na to, co sprawia, że spory o przeszłość i jej interpretację, stają się elementem napiętnowania i wykluczenia. Czy nie godzimy się na obecność w dyskursie publicznym tego rodzaju polityki historycznej, która jest nie tyle definiowana, co traktowana jako prosty - i trzeba dodać niezwykle skuteczny - instrument propagandy, przed którym przestrzega Pomorski kiedy pisze o pułapkach na jakie narażony jest homo metahistoricus ${ }^{7}$, używany dla promocji i perswazji nie tylko określonych wizji przeszłości, ale przede wszystkim „właściwych” postaw i wartości, wyznaczających ramy nie tylko myślenia o przeszłości/ jej możliwych do pomyślenia i zwerbalizowania (zwizualizowania) interpretacji, ale i możliwych do podjęcia i pożądanych działań. Oto operacjonalizacja narzędzia, które każe nam bezrefleksyjnie „odbierać” $\mathrm{i}$ „powielać” płynące z „ośrodka władzy” przekazy/wizje/ wizerunki dziejów, zamiast budzić w nas skłonność do refleksji nad (naszą) historią, do myślenia historycznego, w którym postrzegamy siebie (jednostkę) jako jej twórcę/ kreatora - Pomorski określa go mianem homo historicus ${ }^{8}$ - a nie bezwolnego wykonawcę dyrektyw wynikających z narzuconych myśleniu, wyimaginowanych praw/ sil/ procesów historycznych. Świadomość społeczna/historyczna konstytuowana w oparciu o z góry ustalone, a następnie narzucane członkom społeczeństwa, wartości i postawy, które kryją się za wizerunkami przeszłości obecnymi w tak rozumianej polityce historycznej, nie tylko nie powinna i nie może stać za pozytywnie rozumianą socjalizacją, ale w żaden sposób nie sprzyja temu, co J. Pomorski określił mianem budowy kapitału spotecznego, nie gwarantuje wreszcie realizacji podstawowych funkcji, które pełni bądź ma pełnić wobec społeczeństwa nauka.

Modna i ciągle wpływowa koncepcja zarządzania ryzykiem, podpowiada nam, iż winniśmy nie tylko oszacować konsekwencje jakie kryją się za przyjmowaniem i odwzorowywaniem narzucanych przez ośrodek władzy politycznej dopuszczanych/ akceptowalnych przedmiotów badań, ich interpretacji czy tworzeniem list „tematów zakazanych", ale każe nam wziąć pod uwagę także sytuację, w której wykluczenie „słabszej”/„nieprawowitej” interpretacji przeszłości pozbawi nas szansy na realizację poznawczych funkcji historii/historiografii. Warto być może zadać sobie na nowo pytanie o to, co tak szczególnego jest obecne w historii, że pozwala nam, a może

7 http://pth.net.pl/uploads/forum_badaczy_dn/Polityzacja_historii.pdf [dostęp: 15-06-2017], s. 1523. Jest to szczególnie mocno widoczne, kiedy mowa o pułapkach, które Pomorski określa jako: historia $w$ stużbie propagandy $i$ historia $w$ stużbie dysfunkcyjnego kapitatu spotecznego oraz nacjonalizmu, tamże, s. 20-22.

8 http://pth.net.pl/uploads/forum_badaczy_dn/Polityzacja_historii.pdf [dostęp: 15-06-2017], s. 6. 
wręcz każe, odwoływać się do niej za każdym razem, kiedy próbujemy integrować/ mobilizować społeczeństwo, nie tyle wokół pożądanych systemów wartości, co raczej czego doświadczamy szczególnie dotkliwie dziś - wokół programów politycznych. Co sprawia, że zamiast myśleć o przyszłości, wracamy - wciąż na nowo - do tego, co było.

Potencjalne odpowiedzi mogą zmierzać w kierunku jakiejś formy racjonalizacji tego typu myślenia. W poszukiwaniu przesłanek stałego używania/nadużywania historii można na przykład brać pod uwagę mechanizmy obecne w koncepcji oswajania świata nieznanego poprzez znany, czy też argumentować, że dużo skuteczniejsze - żeby nie powiedzieć łatwiejsze - niż integracja wokół budowy wizji przyszłości ${ }^{9}$ są zazwyczaj próby mobilizacji/integracji społeczeństwa poprzez odwołanie się do wydarzeń z przeszłości, zwłaszcza tych, które są mocno obciążone emocjami. Wydaje się jednak, że najbardziej oczywistą i wciąż aktualną odpowiedzią pozostają słowa Paula Valery, który już niemal 100 lat temu zauważył, że historia jest

najniebezpieczniejszym wytworem jaki wyprodukowała chemia intelektu. Jej właściwości są dobrze znane. Ona to sprawiła marzenia, ona upaja ludy, tworzy im fałszywe pamiątki, przecenia nad miarę złudzenia, rozdrapuje stare rany, nęka w chwilach wytchnienia, wiedzie do oblędu wielkości lub manii prześladowczej i czyni narody zgorzkniałymi, nieznośnymi, próżnymi. Historia potwierdza wszystko czego się pragnie. Nie naucza ona absolutnie niczego, bowiem zawiera w sobie wszystko i daje odpowiedź na wszystko (...). W obecnym stanie świata, niebezpieczeństwo by dać się uwieść Historii większe jest niż było kiedykolwiek ${ }^{10}$

Przeszłość, pojmowana (już) nie w kategoriach przedmiotu wiedzy (nawiązując do znanej kategorii Krzysztofa Pomiana), ale (ponownie) szeroko rozumianej wiary, staje się - i tak jest uobecniana w przestrzeni publicznej - przedmiotem swoistej manipulacji/konstrukcji. W jej ramach możliwy/potencjalny sens dziejów okazuje się być ładem/porządkiem narzucanym przeszłości przez tych, których dopuszczono do konstytuowania jej obrazów i ujawnia się w próbach ujęcia przeszłości w różnego rodzaju relacje porządkujące/strukturalizujące rzeczywistość, specyficzne dla określonej (lokalnej, a nie uniwersalnej) wspólnoty (kulturowej). I choć zazwyczaj- żeby nie powiedzieć $\mathrm{w}$ „normalnym świecie” - moglibyśmy, a może nawet powinniśmy z nadzieją patrzeć na zjawiska tego typu, w dużej mierze wychodzące naprzeciw dokonującej się „demokratyzacji historii”, wymierzonej nie tyle w monopol historyka

9 Choćby dlatego, że dużo trudniej sterować oczekiwaniami społeczeństwa wobec własnej przyszłości.

10 P. Valery, Regards sur le monde actuel, Paris 1931, 63-64; cyt. za: R. Stobiecki, Historia pod nadzorem, Łódź 1993, s. 21 . 
na konstytuowanie narracji o przeszłości ${ }^{11}$, co raczej dopuszczającej obecność w życiu społecznym/publicznym, różnorodnych - często wykluczających się - narracji/interpretacji przeszłości i odmiennych ich form, to w aktualnej sytuacji nie jest trudno wskazać zagrożenia z niego wynikające.

Po pierwsze, przeszłość pojmowana jako swoisty przedmiot wiary okazuje się bowiem - często wbrew deklaracjom jej adoratorów - rozmywać różnicę między „prawdą nauki” a „prawdą pamięci” (choć oczywiście w tym przypadku można mówić o rożnych „sortach pamięci” - lepszych i gorszych mówiąc wprost, a zatem tych, które „dobrze pamiętają” i tych, które celowo i metodycznie „zakłamują” ${ }^{12}$. Po drugie, jest nim (owym zagrożeniem) programowa ucieczka od odmiennej - niż klasyczna - perspektywy czasowej, werbalizowanej - mocno upraszczając zjawisko - przy pomocy kategorii charakteryzujących „czas historyka” i „czas socjologa”, a więc takiej m.in., w której podstawą interpretacji (i oceny) zjawiska/wydarzenia staje się nie to, co było potem („czas historyka”), ale to, co było znane w momencie podejmowania decyzji przez bohatera narracji historycznej („czas socjologa”) 13 .

Nie można nie zauważyć wreszcie, że z określonego statusu wiedzy historycznej wyprowadza się daleko idące wnioski, nie tylko te odnoszące się do miejsca historiografii w szeroko rozumianej nauce czy funkcjonowania historyków w społecznej praktyce naukowej, ale przede wszystkim te, które określają czy odnoszą się do wiedzy, która jest efektem tej praktyki. Realizacja funkcji społecznych pełnionych przez historiografię - na przykład tych wskazywanych/określanych przez samych historyków $^{14}$ - jest konsekwencją (a nawet jest uzależniona od) takiego, a nie innego statusu wiedzy historycznej. Sytuowanie tej wiedzy w ramach oświeceniowej tradycji filozoficznej, związanej m.in. z określonym pojmowaniem samej nauki, ale także zadań, które ma do spełnienia wobec społeczeństwa, okazuje się być źródłem nie tyle pozycji historyków w ramach kultury/społeczeństwa, co przede wszystkim gwarantem - choć

Zagrożeniem dla (profesjonalnej) historiografii - jak sądzę - nie jest dokonująca się „demokratyzacja historii”, ale zbyt mała obecność, a czasem wręcz niechęć historyków w tych przedsięwzięciach, które ze względu na atrakcyjną i przystępna formę (czasem także treści) - zwłaszcza dla młodego odbiorcy - cieszą się stale rosnącą popularnością, a które są istotnymi elementami kultury (popkultury) m.in. przez fakt łatwego i szybkiego do nich dostępu. Więcej patrz: M. Woźniak, Przeszłość jako przedmiot konstrukcji, Lublin 2010.

12 Jedną z wielu ilustracji tego typu myślenia (niemyślenia?) o przeszłości, w którym „prawda pamięci” zyskuje status „prawdy nauki” jest na przykład tekst Anny Zechenter zamieszczony na stronach Instytutu Pamięci Narodowej: http://www.ipn.gov.pl/pl/aktualnosci/39858,Brygada-Swietokrzyska-NSZ-ocalila-wiezniarki-niemieckiego-obozuw-Holiszowie.html [dostęp: 15-06-2017]. Mechanizmy tego typu mitologizacji/ polityzacji odsłania na przykład Rafał Wnuk (http://wyborcza.pl/alehistoria/1,121681,19518952,brygada-swietokrzyska-zaklamana-legenda. html?disableRedirects=true [dostęp: 15-06-2017]), pokazując jednocześnie „inną twarz” - w pewnym sensie podejmując się próby demitologizacji - kreowanego przez instytucje państwowe mitu.

13 Na co zwraca uwagę także Pomorski: http://pth.net.pl/uploads/forum_badaczy_dn/Polityzacja_historii. pdf [dostęp: 15-06-2017], s. 15-16. Więcej patrz: M. Woźniak, Przeszłość jako przedmiot konstrukcji, s. 74-77.

14 Patrz np.: Spoteczna funkcja historii a wspótczesność, red. Z. Mańkowski, J. Pomorski, Lublin 1985. 
nie z punktu widzenia jakości narracji historycznej - realizacji przypisanych historii funkcji poznawczych (także społecznych i kulturowych). Nie przypadkowo zatem przymiotnik naukowy - wraz z kryjącymi się za nim wartościami - przypisuje się dziś historykom związanym z propagowaną przez ośrodek władzy wizją/interpretacją przeszłości, pozostałych zaś określa się mianem „publicystów”|5. Nie trzeba tu szczególnych profetycznych zdolności, by wyobrazić sobie sytuację, w której aktualne spory o ocenę i stosunek do „żołnierzy wyklętych/niezłomnych”, zostaną zastąpione - o ile już nie są - sporami o ocenę i stosunek do „wyklętych/niezłomnych historyków”.

O ile należy się zgodzić z (pierwszą częścią) postawionej przez Pomorskiego tezy, w której przekonuje, że szanse historiografii na efektywny wkład w budowę kapitału społecznego oraz trwałą obecność w nauce i życiu publicznym, można/powinniśmy wiązać w realizowaniu jej podstawowej funkcji poznawczej, czyli rozpoznawaniu $<<$ gramatyk >> sterujacych poszczególnymi rodzajami praktyk spotecznych $w$ dziejach ( $w$ tym praktyki politycznej), o tyle moje wątpliwości budzi - zwłaszcza w obecnej sytuacji społeczno-politycznej, wraz z obecnymi w niej podziałami na „lepszy i gorszy sort” historyków - dalsza jej część. Trudno bowiem, moim zdaniem, doszukiwać się pozytywnych konsekwencji - przynajmniej w odniesieniu do tego, jak to wygląda we współczesnej/codziennej praktyce - w realizowaniu jej funkcji społecznej, czyli zdolności do wypracowania konsensusu w sprawie tego, co nazywam historycznym bezpieczeństwem ontologicznym wspólnoty (czytaj tu: Polski) i jej zdolnością do zmiany zastanego porządku, czyli do tworzenia Historii ${ }^{16}$, w sytuacji, gdy - jak to zostało wskazane wyżej - polityka historyczna/pamięci staje się, czy jest używana jako narzędzie prymitywnej propagandy. Ewentualny konsensus odnośnie naszej (i nie tylko naszej) przeszłości nie jest możliwy, i mam nadzieję, nie będzie, bo nie może być możliwy jako efekt zgody (czy jej konsekwencja) na historię/narrację jednowymiarową, czarno-białą, w której pomija się niewygodne fakty (jak np. w przypadku biografii majora Leonarda Zub-Zdanowicza) ${ }^{17}$, zaś wydarzenia/zjawiska nie będące powodem do dumy (jak w przypadku pogromu Kieleckiego czy też Jedwabnego) usuwa się z kart historii, bądź próbuje się im nadać sens i znaczenie inne, niż wskazują na to dostępne materiały źródłowe ${ }^{18}$. Nie ma mowy o kompromisie w sytuacji, gdy „myślących inaczej”, przedstawiających odmienną od oficjalnej (akceptowanej przez ośrodki władzy) wizję/interpretację przeszłości,

15 Jak w przypadku znanego i cenionego badacza powojennego podziemia niepodległościowego profesora Rafała Wnuka.

16 http://pth.net.pl/uploads/forum_badaczy_dn/Polityzacja_historii.pdf [dostęp: 15-06-2017], s. 4.

17 Patrz np.: http://janzaryn.pl/?p=2394; https://dorzeczy.pl/26393/Leonard-Zub-Zdanowicz-list-wobronie-oficera-Brygady-Swietokrzyskiej.html [dostęp: 15-06-2017].

18 Patrz np.: https://dorzeczy.pl/kraj/9358/Czego-nie-wiemy-o-Jedwabnem-i-Kielcach.html [dostęp: 15-06-2017]. 
wyklucza się/ etykietyzuje/stygmatyzuje/sortuje ${ }^{19}$, pozbawia się głosu, a w skrajnych przypadkach próbuje się także pozbawić pracy (jak we wspomnianym już przypadku jednego z pracowników lubelskiego oddziału Instytutu Pamięci Narodowej) ${ }^{20}$.

Nie będę próbował w tym miejscu dociekać, czy w ogóle potrzebujemy jakiejś formy konsensusu co do treści (i formy) naszych (możliwych) wizerunków przeszłości. Powiem jedynie, że w moim przekonaniu, wspomniany przez Pomorskiego kompromis jest możliwy jedynie w sytuacji kiedy dopuszczalne, możliwe do zaoferowania są tak różnorodne formy wypowiedzi o przeszłości, jak przede wszystkim różne/odmienne, czasem sprzeczne ze sobą wizje/narracje/interpretacje/konceptualizacje przeszłości. Wtedy zatem, gdy odmienny, konstytuowany przy udziale nie sprzecznych z zasadami zapisanymi w warsztacie - a właściwie warsztatach - historyka, obraz przeszłości nie stanie się przyczyną wykluczenia, a próby wyjaśnienia, opisu, czy jedynie przedstawienia niewygodnych zjawisk i wydarzeń nie będzie zagrożone marginalizacją i stygmatyzacją (czy wręcz procesem karnym). Na pewno zatem nie ma możliwości uzyskania jakieś formy kompromisu, w sytuacji, kiedy próbuje się go uzyskać/budować - a w zasadzie narzucić - w oparciu o przedstawioną wyżej koncepcję uprawiania polityki historycznej. Co więcej, uznając spory o historię (podobnie zresztą jak o politykę) za coś naturalnego, jak deklarowałem na początku tekstu, stoję na stanowisku, iż tak jak w nauce historycznej obecność różnorodnych/możliwych interpretacji i obrazów przeszłości, jest (a przynajmniej może i powinna być) warunkiem jej rozwoju, a co za tym idzie także wzrostu wiarygodności wiedzy, którą oferuje, tak też w przypadku budowania kapitału społecznego. Nie tylko nie potrzebujemy jednej/prawomyślnej wizji naszej przeszłości, ale jestem przekonany, iż wytworzenie tych aktywów, które Pomorski łączy z owym kapitałem - jak zaufanie, wspólnie podzielane idee czy przekonania - jest możliwe jedynie w sytuacji i przy udziale swobodnego tworzenia i dostępu do różnorodnych/odmiennych, tak w treści jak i formie, narracji/interpretacji przeszłości. Warto wreszcie przypominać (być może ciągle na nowo), że zmiany jakie możemy obserwować w konstytuowanych przez historyków obrazach przeszłości (jej fragmentów), nie są konsekwencją tego, że zmieniła się sama przeszłość, ale tego, że doświadczamy jej w taki czy inny sposób. Są ostatecznie świadectwem tego, w jaki

19 Patrz np.: http://isakowicz.pl/atak-lewicowych-autorytetow-moralnych-na-wojewode-z-lublina/ [dostęp: 15-06-2017]; https://dorzeczy.pl/kraj/27236/Rykoszetem-w-bohatera.html [dostęp: 15-06-2017]; http:/ wiadomosci.onet.pl/kraj/kolejni-historycy-na-celowniku-politykow-za-zbyt-krytyczne-oceny-zolnierzywykletych/nb26lz5 [dostęp: 15-06-2017]; http://www.sejm.gov.pl/Sejm8.nsf/InterpelacjaTresc.xsp?key=2A8E1300 [dostęp: 15-06-2017]; https://lublin.tvp.pl/30164099/28-kwietnia [dostęp: 15-06-2017] (od ok.4.45 min.); http://lublin.wyborcza.pl/lublin/7,48724,21765690,eleganccy-ludzie-i-telewizja-narodowa-felieton.html [dostęp: 15-06-2017].

20 Patrz: przypis 6. 
sposób radzimy sobie z tą przeszłością. Spojrzenie na historiografię jako autorefleksję pokolenia historyków (kultury badającej) ${ }^{21}$, jako rezerwuaru możliwych sposobów doświadczania (i konstytuowania wizerunków) przeszłości, pozwala nam nie tylko zmieniać i odsłaniać kolejne fragmenty dziejów (bądź doprecyzowywać wiedzę o nich), ale także, a w naszym przypadku przede wszystkim, pozwala nam traktować ją (historiografię) jako źródło wiedzy o możliwościach (i granicach) poznawczych oraz o gramatyce kultury konstytuującej takie, a nie inne wizerunki przeszłości (i ich formy).

Nie da się nie dostrzec, iż przeszłość, jej wizerunki - zwłaszcza te związane z najnowszą historią Polski - stanowią istotny element (szeroko rozumianych) współczesnych dyskursów publicznych. Trzeba sobie jednak jasno powiedzieć, iż obecne w nich konceptualizacje/interpretacje przeszłości służą nie tylko popularyzacji historii, ale stają się często orężem w walce politycznej. W konsekwencji, tak jak nie powinniśmy uciekać od pytań o cele „używania/nadużywania” historii i projektowaną dla niej rolę $\mathrm{w}$ różnych praktykach społecznych, tak jednym z podstawowych zadań, które stoją przed historykami, jest refleksja nad teorią i praktyką form uobecniania przeszłości w przestrzeni publicznej, nad funkcją/zadaniem/rolą jaką pełnią/ mają pełnić wobec społeczeństwa, a wreszcie nad miejscem w niej historii/historiografii akademickiej. Nie powinniśmy przy tym zapominać, że polityka historyczna/pamięci jest/ okazuje się być niczym innym jak polityką właśnie - tak jak ekonomiczna, społeczna, kulturalna, edukacyjna - i ma/powinna realizować inne cele niż historiografia. Problemy i wątpliwości - a w pewnym sensie i niebezpieczeństwa związane z pulapkami, na które narażony jest homo metahistoricus - pojawiają się w momencie, kiedy politykę historyczną państwa/władzy realizować ma historiografia.

Przyjmując - w tym miejscu umownie - że każda praktyka społeczna (prawna, religijna, polityczna, kulturalna, medialna, kulinarna, naukowa, itd.) posługuje się w realizacji zapotrzebowania na właściwe sobie wartości, określonym dyskursem adaptującym na swoje potrzeby pewne interpretacje (i formy) przeszłości, nie powinniśmy jednocześnie zamykać się na odmienności. Wielość funkcjonujących obok siebie, często wykluczających się wzajemnie, narracji/wizualizacji/konceptualizacji przeszłości w nich obecnych, nie tylko nas (społeczeństwo) wzbogacają, ale skłaniają do stawiania pytań o przyczyny takiego stanu rzeczy, ale także o związki między narastającym różnicowaniem się dyskursów (i ich form) o przeszłości, a zmianami w sferze publicznej/społecznej. Zadania, które stawia się przed nami (historykami), a które są w jakieś mierze efektem oceny ryzyka jakie niesie za sobą mitologizacja/ polityzacja historii, powinny się sprowadzać zatem tak do namysłu nad przyczynami

21 Por.: J. Pomorski, Historiografia jako autorefleksja kultury badającej, w: Świat historii, red. W. Wrzosek, Poznań 1998. 
stale rosnącego znaczenia obrazów/interpretacji przeszłości w życiu społecznym i politycznym, jak i - a może przede wszystkim - do refleksji nad formami i narzędziami jej przedstawiania/reprezentacji. W jakieś mierze można bowiem uznać czy założyć, że jej (mitologizacji/polityzacji) źródła leżą nie tylko w naszej - ludzkiej - potrzebie przeżywania świata/przeszłości jako sensownego/sensownej, ale także w związanych z nią sposobami konceptualizacji/narratywizacji/wizualizacji historii. I tak jak jest oczywiste, że kłopot - z punktu widzenia funkcjonowania nauki historycznej, wiedzy, którą dostarcza, ale także względem budowy tworzenia aktywów kapitału społecznego - zaczyna się w momencie kiedy źródłem mitologizacji/polityzacji przeszłości/historii staje się potrzeba sterowania świadomością (nie tylko historyczną) zbiorowości, a w efekcie także wyobraźnią i emocjami, a zatem wtedy, kiedy pilotowane przez państwo/ partię polityczną wizje przeszłości stają się fundamentem podejmowanych działań i rozstrzygnięć ustawodawczych (ustrojowych/ prawnych/ekonomicznych/edukacyjnych/kulturalnych). Zgadzając się z Pomorskim, kiedy wskazuje na konieczność odróżnienia sprawcy historii (homo historicus) i reflektującego nad historią (homo metahistoricus), i przyjmując, że najważniejszym zadaniem tego drugiego winny być próby odstonięcia GRAMATYKI HISTORII, jako wtaściwego przedmiotu POZNANIA ${ }^{22}$, wierzę, że jedną z dróg/ jednym z etapów do tego prowadzących mogłaby być - a może nawet powinna - refleksja nad formami i narzędziami przedstawiania/reprezentacji przeszłości, gdyż w moim przekonaniu nie tylko określa ona możliwości poznawcze historii/historiografii, ale w jakiejś mierze odsłania też fundamenty kultury, w której powstają. Obok tego zaś ponowny namysł nad źródłami mitologizacji/polityzacji historii, uwzględniający owe formy i narzędzia, ale jednocześnie kładący nacisk na założenia przyjmowane w trakcje budowy/tworzenia określonych wizerunków przeszłości - konstytuowane tak w ramach wizji świata i człowieka, jak szeroko rozumianego światooglądu - i treści będące ich konsekwencją.

22 http://pth.net.pl/uploads/forum_badaczy_dn/Polityzacja_historii.pdf [dostęp: 15-06-2017], s. 24. Przy czym Pomorski przedmiot poznania historycznego odróżnia od przedmiotu badania historycznego, uznając, że ten ostatni sprowadza się do tematów, jakie w pracach historyków są podejmowane. 